\title{
Formation of Ln-Si-Al-O-N Glasses and their Properties
}

\author{
R. Ramesh, E. Nestor, M. J. Pomeroy and S. Hampshire
}

Materials Research Centre, University of Limerick, Ireland

\begin{abstract}
The preparation details of bulk glasses in the $\mathrm{Ln}-\mathrm{Si}$ $A l-O-N$ systems ( $L n=Y, C e, N d, S m, E u, D y, H o$ and Er) containing 17 equivalent \% nitrogen are reported. The properties of these oxynitride glasses are examined in detail. Changes observed in density, molar volume, hardness, thermal expansion and glass transition temperature are presented and are found to vary linearly with the cationic field strength or ionic radius of the rare earth modifier. The implications for changes in glass structure caused by the substitution of one rare earth cation for another are discussed in relation to the property changes observed. (C) 1997 Elsevier Science Limited.
\end{abstract}

\section{Résumé}

La préparation du verre massif dans les systèmes $\mathrm{Ln}-\mathrm{Si}-\mathrm{Al}-\mathrm{O}-\mathrm{N}$ ( $\mathrm{Ln}=\mathrm{Y}, \mathrm{Ce}, \mathrm{Nd}, \mathrm{Sm}, \mathrm{Eu}, \mathrm{Dy}, \mathrm{Ho}$ et Er) contenant $17 \%$ équivalent d'azote, est détaillée. Les propriétés de ces verres oxynitrurés sont éxaminées en détail. Les changements de densité, de volume molaire, de dureté, de dilatation thermique et de température de transition vitreuse observés, sont présentés, et nous avons trouvé des variations linéaires avec le champ de force cationique ou le rayon ionique de la terre rare modificatrice. Les conséquences sur la structure vitreuse, de la substitution d'un cation de terre rare par un autre, sont traitées en relation avec les changements de propriétés observés.

\section{Introduction}

The requirement of an oxide additive for the liquid phase pressureless densification of $\mathrm{Si}_{3} \mathrm{~N}_{4}$ and $\beta$-sialon ceramics is now well established. ${ }^{1} \mathrm{At}$ temperatures $>1350^{\circ} \mathrm{C}$, the additive, usually a metal oxide, reacts with the surface silica of $\mathrm{Si}_{3} \mathrm{~N}_{4}$ particles and some of the nitride to form an oxynitride liquid which on cooling remains as an intergranular glass. ${ }^{2}$ Such oxynitride glass phases can impair subsequent high temperature mechanical properties. ${ }^{3}$ Refractory metal oxides such as $\mathrm{Y}_{2} \mathrm{O}_{3}$ have been used in an attempt to increase the softening temperature of the intergranular glass. ${ }^{4}$ Numerous studies of various $\mathrm{M}-\mathrm{Si}-\mathrm{Al}-\mathrm{O}-\mathrm{N}$ bulk glasses $(\mathrm{M}=\mathrm{Y}, \mathrm{Mg}, \mathrm{Ca}, \mathrm{Nd})$ have since followed and these studies have shown oxynitride glasses to possess higher refractoriness, elastic modulus and hardness compared to the corresponding oxide glasses. ${ }^{5-8}$ The use of lanthanide oxides as sintering additives has been explored, $, 9,10$ but these earlier investigations mainly pertained to specific properties and not on the ability of the rare-earth ion to act as primary component of the glass structure. The advantages of using lanthanide metal oxides in the preparation of oxynitride glasses are three-fold: ${ }^{11}$ (i) nitrogen has a higher solubility in $\mathrm{Ln}-\mathrm{Si}-\mathrm{Al}-\mathrm{O}-\mathrm{N}$ glasses $(>25 \mathrm{a} / \mathrm{o})$ than in other $\mathrm{M}-\mathrm{Si}-\mathrm{Al}-\mathrm{O}-\mathrm{N}$ glasses and the glassy grain boundary phases in silicon nitride densified with these oxides are considered to posess higher refractoriness; (ii) viscosities of some Ln-Si-Al-O-N liquids for a given level of nitrogen are less than those of the equivalent $\mathrm{Y}-\mathrm{Si}-\mathrm{Al}-\mathrm{O}-\mathrm{N}$ liquids and this promotes easier densification of silicon nitride/sialons; (iii) Ln cations can be accommodated in the interstitial sites in the $\alpha$-sialon lattice, thus providing an opportunity for these additives to form transient liquid phases during sintering, and a reduced amount of grain boundary glass. In spite of these advantages, only limited research has been carried out on oxynitride glasses in lanthanide systems. Recently, Murakami and Yamamoto ${ }^{12}$ studied the effect of radius of rare-earth ions on the characteristics of various $\mathrm{Ln}-\mathrm{Si}-\mathrm{Al}-\mathrm{O}-\mathrm{N}$ glasses but these studies were confined to determining the glass transition and softening temperatures and the oxidation resistance. The results indicated that the oxidation resistance of the glasses increased with decreasing radius of the rare-earth cation, but little 
correlation was found between the glass transition and softening temperatures and the cationic radius. In contrast, Ohashi et al. ${ }^{13}$ have observed a good correlation between the glass transition temperature and cationic radius in the $\mathrm{Ln}-\mathrm{Si}-\mathrm{O}-\mathrm{N}$ systems. The density, Young's modulus and glass transition temperature were found to increase while molar volume decreases with decreasing cationic radius. In this paper, the effect of the substitution of lanthanide cations on the bulk density, hardness, thermal expansion, viscosity and molar volume are examined along with the glass transition and crystallisation temperatures for various $\mathrm{Ln}-\mathrm{Si}-\mathrm{Al}-\mathrm{O}-\mathrm{N}$ glasses and compared with changes in the cationic field strength of the modifying cation.

\section{Experimental Procedure}

\subsection{Composition selection and glass preparation}

Bulk glasses in $\mathrm{Ln}-\mathrm{Si}-\mathrm{Al}-\mathrm{O}-\mathrm{N}$ systems $(\mathrm{Ln}=\mathrm{Ce}$, $\mathrm{Nd}, \mathrm{Sm}, \mathrm{Eu}, \mathrm{Dy}, \mathrm{Ho}$ and $\mathrm{Er}$ ) containing 17 equivalent $\%$ nitrogen have been selected for investigation. The chosen $\mathrm{Ln}-\mathrm{Si}-\mathrm{Al}-\mathrm{O}-\mathrm{N}$ glasses had a nominal composition corresponding to 28Ln: 56Si: $16 \mathrm{Al}: 83 \mathrm{O}: 17 \mathrm{~N}$ (in equivalent \%) or 12.3Ln: $18.5 \mathrm{Si}: 7 \mathrm{Al}: 54.7 \mathrm{O}: 7.5 \mathrm{~N}$ (in atomic percent). In addition, a $\mathrm{Y}-\mathrm{Si}-\mathrm{Al}-\mathrm{O}-\mathrm{N}$ glass of similar composition was prepared and this was used as a standard reference system for comparison with glasses prepared using various other rare-earth cations. The method of representation of components in equivalent units has been reported previously. ${ }^{8}$

$\mathrm{Y}_{2} \mathrm{O}_{3}, \mathrm{Nd}_{2} \mathrm{O}_{3}, \mathrm{Sm}_{2} \mathrm{O}_{3}, \mathrm{Eu}_{2} \mathrm{O}_{3}, \mathrm{Dy}_{2} \mathrm{O}_{3}, \mathrm{Ce}_{2} \mathrm{O}_{3}$, $\mathrm{Ho}_{2} \mathrm{O}_{3}$ and $\mathrm{Er}_{2} \mathrm{O}_{3}$ with $99.9 \%$ purity (Rare Earth Products Ltd.) were used. The manufacturer's certificate of analysis indicates the presence of $\mathrm{Ca}, \mathrm{Si}$ and $\mathrm{Al}$ (1-20 ppm level) as the common metal impurities present in the rare-earth oxides. $\mathrm{Al}_{2} \mathrm{O}_{3}$ was analar grade (BDH) with the maximum limit of impurities given as water soluble matter $(0.2 \%)$, chloride, sulphate and $\mathrm{Fe}\left(0.005 \%\right.$ each). $\mathrm{SiO}_{2}$ was from Fluka Chemicals Ltd and had $\mathrm{Ca}(0.02 \%), \mathrm{Fe}$ $(0.02 \%), \mathrm{K}(0.05 \%)$ and $\mathrm{Na}(0.01 \%)$ as the major impurities. All oxides were calcined at $900^{\circ} \mathrm{C}$ to remove any volatiles and/or chemically absorbed water and stored in a drying oven at a temperature of $120^{\circ} \mathrm{C}$. The silicon nitride (LC12SX) powder was obtained from Hermann C. Starck, Berlin with an oxygen level of $2.06 \%, \mathrm{C}$ of $0.15 \%$ and negligible traces of $\mathrm{Fe}, \mathrm{Ca}$ and $\mathrm{Al}$ (total less than $0.015 \%$ ). The powders were wet ball milled in isopropanol for $24 \mathrm{~h}$, followed by evaporation of the alcohol before pressing into pellets. Large batches $(50-60 \mathrm{~g})$ were melted in a boron nitride-lined graphite crucible under 1 at. nitrogen pressure at $1700^{\circ} \mathrm{C}$ for $1 \mathrm{~h}$ in a vertical tube furnace, after which the melt was poured into a preheated graphite mould at $850^{\circ} \mathrm{C}$ and annealed for $1 \mathrm{~h}$ prior to slow furnace cooling.

\subsection{Glass characterisation}

\subsection{1 $X$-ray analysis and SEM}

$\mathrm{X}$-ray analysis was carried out using a Philips $\mathrm{X}$-ray powder diffractometer ( $\mathrm{Cu}-\mathrm{K} \alpha$ radiation) in order to detect any crystalline phases present in the glasses. Scanning electron microscopy was used to assess homogeneity.

\subsubsection{Density}

The densities were measured by the Archimedes principle using distilled water as working fluid.

\subsubsection{Microhardness}

Microhardness tests were carried out on the polished glass samples using a Leco microhardness tester. A load of $100 \mathrm{~g}$ was applied to the sample for $15 \mathrm{~s}$. The resulting indentation diagonals were measured to give an estimation of the hardness of the glass.

\subsubsection{Differential thermal analysis}

Differential thermal analysis (DTA) was carried out in order to detect the glass transition temperature $(\mathrm{Tg})$ and crystallisation temperature ( $\mathrm{Tc})$. The instrument used was a Stanton Redcroft 1640 series simultaneous thermo-gravimetric differential analyser. Small samples $(30 \mathrm{mg})$ were analysed in boron nitride-lined platinum crucibles, in a flowing nitrogen atmosphere. $\mathrm{Al}_{2} \mathrm{O}_{3}$ was used as a reference material. The onset point of an endothermic drift on the DTA curve corresponding to the beginning of the transition range is reported as $\mathrm{Tg}$ while the peak of the exotherm is taken as Tc.

\subsubsection{Thermal expansion}

The thermal expansion coefficient was measured in a Netzch (402EP) dilatometer in air on polished glass specimens whose dimensions were approximately $3 \times 3 \times 50 \mathrm{~mm}^{3}$. The temperature was increased at a rate of $5^{\circ} \mathrm{C} \mathrm{min}^{-1}$ and the change in length over the original length (d1/lo) was recorded for each glass specimen as a function of temperature, from room temperature up to $900^{\circ} \mathrm{C}$. The mean thermal expansion coefficients $(\alpha)$ were calculated between 20 and $800^{\circ} \mathrm{C}$ using the following equation:

$$
\alpha=\left(\Delta \mathrm{l} / \mathrm{l}_{\mathrm{o}}\right) / \Delta \mathrm{T}
$$

where $l_{o}$ is the original length, $\Delta l$ is the change in length of the specimen and $\Delta T$ is the temperature change. 


\subsubsection{Viscosity}

Viscosity was deduced from creep tests performed in air between 750 and $1000^{\circ} \mathrm{C}$ in 3-point bending with a span of $21 \mathrm{~mm}$ on bars with the following dimensions: $25 \mathrm{~mm} \times 4 \mathrm{~mm}$ (width) $\times 3 \mathrm{~mm}$ (height). The expression for the viscosity, $\eta$ is based on the strong analogy existing between the stress/strain relations in an elastic solid and those governing a viscous fluid: ${ }^{14}$

$$
\eta=\sigma /[2(1+v) \varepsilon]
$$

where $\sigma$ and $\varepsilon$ are the applied stress and the creep rate on the outer tensile fibre and $v$ is Poisson's ratio. A value of 0.5 was used for $v$ in the calculations.

\section{Results and Discussion}

\subsection{Quality and homogeneity assessment of glasses}

$\mathrm{X}$-ray analysis and observations on melting for standard rare-earth compositions containing 17 equivalent $\%$ (e/o) $\mathrm{N}$ are shown in Table 1. All the compositions were observed to be X-ray amorphous and, in addition, SEM analysis showed these glasses to be homogeneous. Similar work performed earlier in the oxide systems ${ }^{15}$ also showed that glasses can be made in a wide range of rareearth aluminosilicate systems. These studies tend to imply that the structural role of the rare-earth cation must be unique to allow formation of glasses with relative ease.

Substitution of one $\mathrm{Ln}$ cation for another in the $\mathrm{Ln}-\mathrm{Si}-\mathrm{Al}-\mathrm{O}-\mathrm{N}$ systems results in a change in the colour of the glass. Various colours were observed ranging from wine through green and blue to black depending on the rare-earth metal cation used. The analysis for nitrogen content carried out using Carlo Erba 1106 equipment showed only a small loss of $3-4 \%$ of total nitrogen content for all the compositions.

\subsection{Density}

Table 2 compares the densities of $\mathrm{M}-\mathrm{Si}-\mathrm{Al}-\mathrm{O}-\mathrm{N}$ $(\mathrm{M}=\mathrm{Y}, \mathrm{Ln})$ glass compositions. As can be seen, the density of the glasses, in general, increases with an increase in rare-earth atomic number with the exception of the Eu-containing composition. This increase in density with increasing atomic number is primarily due to the increased atomic weights of the modifying cation, M. However, it may also be due to the increasing cationic field strength $\left(z / r^{2}\right.$ : valence (z), bond length of $\mathrm{Ln}-\mathrm{O}(\mathrm{r})$ ) of the $\mathrm{Ln}$ cations between $\mathrm{Ce}$ and $\mathrm{Er}$ (Fig. 1). The values used for ionic radii are included in Table $2 .^{16}$

The ionic radius of the lanthanides decreases with increasing atomic number because of the lanthanide contraction. As a result, the effective force attracting anions (ie. the cationic field strength) increases. Consequently, the glass network becomes more compact resulting in the observed increased density. ${ }^{13}$ The decrease in density observed for $\mathrm{Eu}-\mathrm{Si}-\mathrm{Al}-\mathrm{O}-\mathrm{N}$ glass may perhaps be attributed to the oxidation state of the Eu cation. $\mathrm{Eu}$ can exist either as $\mathrm{Eu}^{2+}$ or $\mathrm{Eu}^{3+}$ and, in the $\mathrm{Eu}^{2+}$ state, it reduces the strength and increases the length of the $\mathrm{Eu}-\mathrm{O}$ bond thercby lowering the density. Recent structural studies confirm Eu to be in the $\mathrm{Eu}^{2+}$ state. ${ }^{17}$ Therefore, a new value of

Table 1. Analysis of glass compositions

\begin{tabular}{lccc}
\hline Material & Compositions $(e / o)$ & $X$-ray analysis & Observation on melting \\
\hline Y-Si-Al-O-N & $28 \mathrm{Y}: 56 \mathrm{Si}: 16 \mathrm{Al}: 83 \mathrm{O}: 17 \mathrm{~N}$ & Amorphous & Grey glass disc \\
$\mathrm{Ce}-\mathrm{Si}-\mathrm{Al}-\mathrm{O}-\mathrm{N}$ & $28 \mathrm{Ce}: 56 \mathrm{Si}: 16 \mathrm{Al}: 83 \mathrm{O}: 17 \mathrm{~N}$ & Amorphous & Grey glass bar \\
$\mathrm{Nd}-\mathrm{Si}-\mathrm{Al}-\mathrm{O}-\mathrm{N}$ & $28 \mathrm{Nd}: 56 \mathrm{Si}: 16 \mathrm{Al}: 83 \mathrm{O}: 17 \mathrm{~N}$ & Amorphous & Navy blue glass bar \\
$\mathrm{Sm}-\mathrm{Si}-\mathrm{Al}-\mathrm{O}-\mathrm{N}$ & $28 \mathrm{Sm}: 56 \mathrm{Si}: 16 \mathrm{Al}: 83 \mathrm{O}: 17 \mathrm{~N}$ & Amorphous & Black glass bar \\
$\mathrm{Eu}-\mathrm{Si}-\mathrm{Al}-\mathrm{O}-\mathrm{N}$ & $28 \mathrm{Eu}: 56 \mathrm{Si}: 16 \mathrm{Al}: 83 \mathrm{O}: 17 \mathrm{~N}$ & Amorphous & Dark green glass bar \\
$\mathrm{Dy}-\mathrm{Si}-\mathrm{Al}-\mathrm{O}-\mathrm{N}$ & $28 \mathrm{Dy}: 56 \mathrm{Si}: 16 \mathrm{Al}: 83 \mathrm{O}: 17 \mathrm{~N}$ & Amorphous & Green glass bar \\
$\mathrm{Ho}-\mathrm{Si}-\mathrm{Al}-\mathrm{O}-\mathrm{N}$ & $28 \mathrm{Ho}: 56 \mathrm{Si}: 16 \mathrm{Al}: 83 \mathrm{O}: 17 \mathrm{~N}$ & Amorphous & Wine coloured glass bar \\
Er-Si-Al-O-N & $28 \mathrm{Er}: 56 \mathrm{Si}: 16 \mathrm{Al}: 83 \mathrm{O}: 17 \mathrm{~N}$ & Amorphous & Wine coloured glass bar \\
\hline
\end{tabular}

Table 2. Densities of standard MSiAlON glass compositions

\begin{tabular}{|c|c|c|c|c|}
\hline Material & $\begin{array}{l}\text { At. no. of rare- } \\
\text { earth cation }\end{array}$ & $\begin{array}{l}\text { Ionic radius } \\
\qquad(\AA)\end{array}$ & $\begin{array}{c}\text { Cationic field strength } \\
\qquad\left(\AA^{-2}\right)\end{array}$ & $\begin{array}{l}\text { Density } \\
\left(\mathrm{g} \mathrm{cm}^{-3}\right)\end{array}$ \\
\hline $\mathrm{Y}-\mathrm{Si}-\mathrm{Al}-\mathrm{O}-\mathrm{N}$ & 39 & 0.893 & 3.76 & 3.75 \\
\hline $\mathrm{Ce}-\mathrm{Si}-\mathrm{Al}-\mathrm{O}-\mathrm{N}$ & 58 & 1.036 & 2.8 & 4.25 \\
\hline $\mathrm{Nd}-\mathrm{Si}-\mathrm{Al}-\mathrm{O}-\mathrm{N}$ & 60 & 0.995 & 3.03 & $4 \cdot 50$ \\
\hline $\mathrm{Sm}-\mathrm{Si}-\mathrm{Al}-\mathrm{O}-\mathrm{N}$ & 62 & 0.964 & 3.23 & $4 \cdot 64$ \\
\hline $\mathrm{Eu}-\mathrm{Si}-\mathrm{Al}-\mathrm{O}-\mathrm{N}$ & 63 & 0.951 & $3 \cdot 32\left(\mathrm{Eu}^{3+}\right) ; 2 \cdot 21\left(\mathrm{Eu}^{2+}\right)$ & 4.40 \\
\hline Dy-Si-Al-O-N & 66 & 0.908 & 3.64 & 4.90 \\
\hline $\mathrm{Ho}-\mathrm{Si}-\mathrm{Al}-\mathrm{O}-\mathrm{N}$ & 67 & 0.89 & 3.79 & 4.97 \\
\hline $\mathrm{Er}-\mathrm{Si}-\mathrm{Al}-\mathrm{O}-\mathrm{N}$ & 68 & 0.88 & $3 \cdot 87$ & $5 \cdot 04$ \\
\hline
\end{tabular}




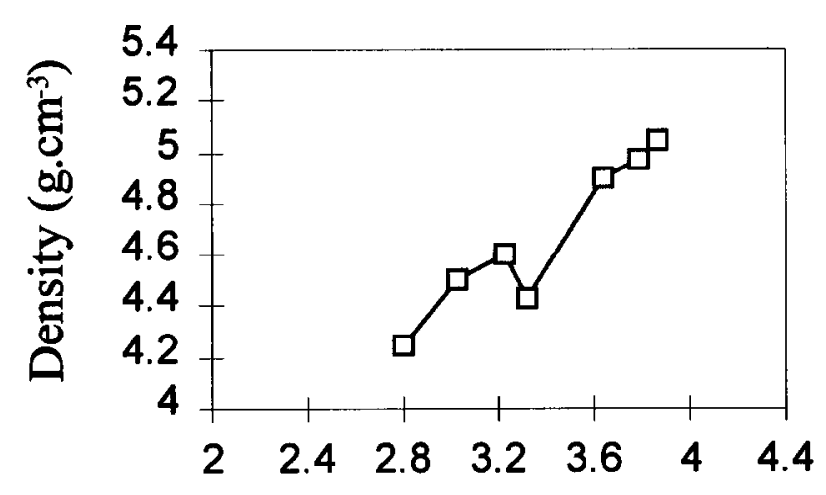

\section{Cationic field strength $\left(\AA^{-2}\right)$}

Fig. 1. The effect of cationic field strength (CFS) on the density of standard $\mathbf{L n}-\mathrm{Si}-\mathrm{Al}-\mathrm{O}-\mathrm{N}$ compositions (data in increasing order of CFS correspond to Ce, Nd, Sm, Eu, Dy, Ho and Er cations).

cationic field strength (CFS) corresponding to the $\mathrm{Eu}^{2+}$ state will henceforth be used $\left(2 \cdot 21 \AA^{-2}\right.$ in place of $3.3 \AA^{-2}$ ). It is known that $\mathrm{Y}, \mathrm{Nd}, \mathrm{Sm}, \mathrm{Dy}$, Ho and Er exist in the $\mathrm{Ln}^{3+}$ state ${ }^{15,18}$ while Ce has two valency states, i.e. $\mathrm{Ce}^{3+}$ and $\mathrm{Ce}^{4+}$. $\mathrm{Ce}$ is known to exist predominantly in the $\mathrm{Ce}^{3+}$ state in cerium aluminosilicate glasses. ${ }^{19}$

The molar volume of the glasses (molecular weight of $\mathrm{Ln}_{9.33} \mathrm{Si}_{14} \mathrm{Al}_{5.33} \mathrm{O}_{41.5} \mathrm{~N}_{5.67} /$ density of glass) calculated from their measured densities is plotted as a function of cationic field strength in Fig. 2. For comparison, data obtained for $\mathrm{Y}-\mathrm{Si}-$ $\mathrm{Al}-\mathrm{O}-\mathrm{N}$ glass has also been included. As can be seen, the molar volumes of the glasses decreases with increasing cationic field strength or, in other words, with decreasing ionic size of the $\mathrm{Ln}^{3+}$ ions, with the exception of the Eu cation. The linear trend of the experimental results follows the expected trend from the volume change caused only by the rare-earth substitution and clearly demonstrates that density increases are controlled by volume contraction as well as by increased $\mathrm{Ln}$ atomic weight.

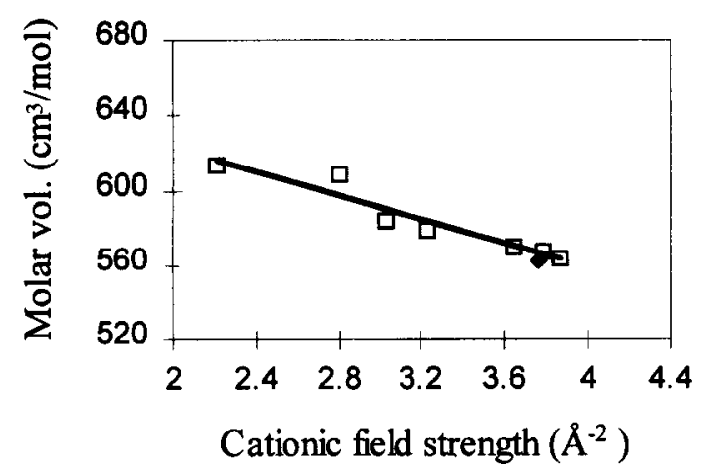

Fig. 2. The effect of cationic field strength (CFS) on the molar volumes of the standard $\mathrm{Ln}-\mathrm{Si}-\mathrm{Al}-\mathrm{O}-\mathrm{N}$ compositions (data in increasing order of CFS correspond to $\mathrm{Eu}, \mathrm{Ce}, \mathrm{Nd}, \mathrm{Sm}, \mathrm{Dy}$, $\mathrm{Y}(\bullet), \mathrm{Ho}$ and Er cations).

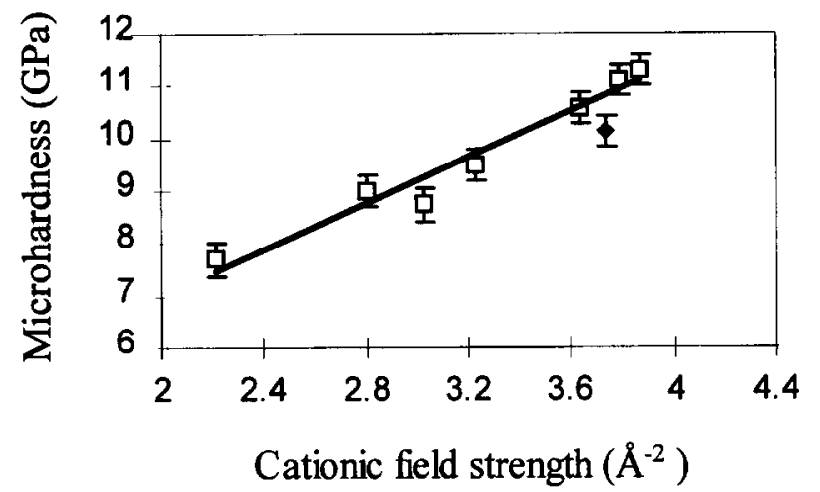

Fig. 3. The effect of cationic field strength (CFS) on the microhardness of the standard $\mathrm{Ln}-\mathrm{Si}-\mathrm{Al}-\mathrm{O}-\mathrm{N}$ compositions (data in increasing order of CFS correspond to $\mathrm{Eu}, \mathrm{Ce}, \mathrm{Nd}$, Sm, Dy, $\mathrm{Y}(\bullet)$, Ho and Er cations).

\subsection{Microhardness}

The effect of cationic field strength on the microhardness of the $\mathrm{Ln}-\mathrm{Si}-\mathrm{Al}-\mathrm{O}-\mathrm{N}$ glasses is shown in Fig. 3. The variation in microhardness observed with increasing cationic field strength is quite significant and increases from $\approx 9 \mathrm{GPa}$ for $\mathrm{Ce}$ to $\approx 11.4 \mathrm{GPa}$ for Er-based glass compositions. This reflects the increases in overall bonding strength of the glasses with decreasing ionic radii of the rareearth cation.

\subsection{Thermal analysis}

The influence of the lanthanide additives on $\mathrm{Tg}$ of the standard $\mathrm{Ln}-\mathrm{Si}-\mathrm{Al}-\mathrm{O}-\mathrm{N}$ compositions are shown in ascending order of their cationic field strength in Fig. 4. As can be seen, $\mathrm{Tg}$ increases linearly with increasing field strength. The $\mathrm{Tg}$ value obtained for the corresponding $\mathrm{Y}-\mathrm{Si}-\mathrm{Al}-\mathrm{O}-\mathrm{N}$ composition is also shown in the plot (diamond marker) and this fits rather well with the observed linear variation between $\mathrm{Tg}$ and the field strength (or ionic radii) in a manner consistent with those of the lanthanide glasses. Figure 5 shows the effect of the lanthanide additives on the crystallisation temperatures of the $\mathrm{Ln}-\mathrm{Si}-\mathrm{Al}-\mathrm{O}-\mathrm{N}$ compositions. For

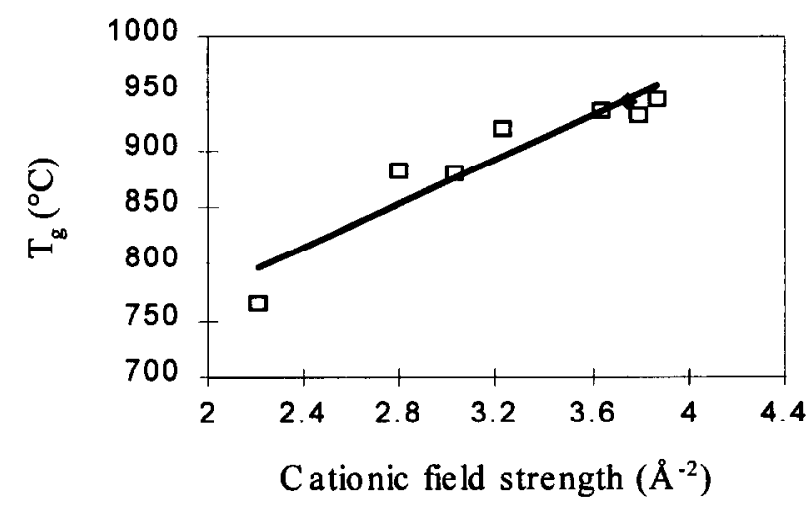

Fig. 4. The effect of $\mathrm{Ln}$ additives on $\mathrm{Tg}$ of the standard glass compositions (data in increasing order of CFS correspond to $\mathrm{Eu}, \mathrm{Ce}, \mathrm{Nd}, \mathrm{Sm}, \mathrm{Dy}, \mathrm{Y}(\bullet), \mathrm{Ho}$ and Er cations). 


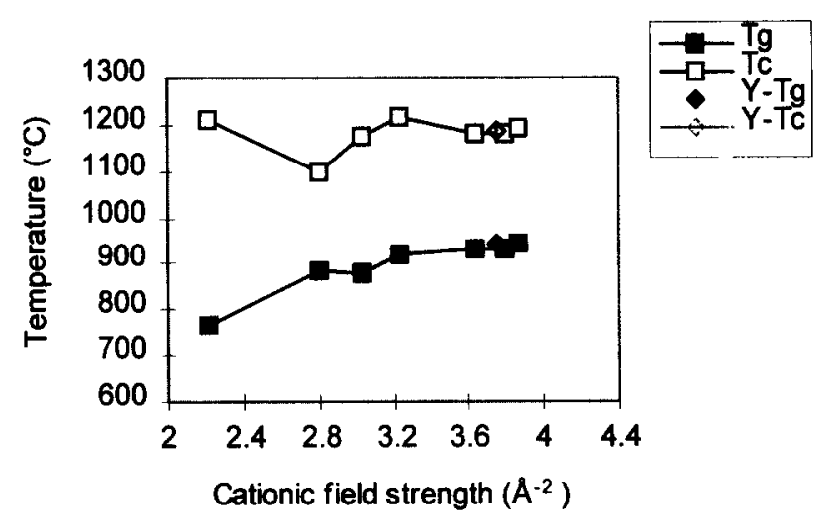

Fig. 5. The effect of Ln additives on Tg and Tc of the standard glass compositions (data in increasing order of CFS correspond to $\mathrm{Eu}, \mathrm{Ce}, \mathrm{Nd}, \mathrm{Sm}, \mathrm{Dy}, \mathrm{Y}, \mathrm{Ho}$ and Er cations).

comparison, corresponding $\mathrm{Tg}$ values shown in Fig. 4 are also included. As can be seen, Tc values exhibit no significant trend with cationic field strength. However, for glass compositions containing cations with higher field strength values (Dy, Y, Ho and Er glasses), the differences noticed between $\mathrm{Tg}$ and $\mathrm{Tc}$ are lower compared to those observed with lower cationic field strength glass compositions (with the exception of Ce glass).

\subsection{Thermal expansion}

The effect of $\mathrm{Ln}-\mathrm{Si}-\mathrm{Al}-\mathrm{O}-\mathrm{N}$ glass composition on thermal expansion coefficient shown in Fig. 6 again indicates the existence of a linear trend. The expansion coefficients of $\mathrm{Ln}-\mathrm{Si}-\mathrm{Al}-\mathrm{O}-\mathrm{N}$ glasses decrease linearly with increasing CFS (decreasing ionic radii) of the rare-earth cation. The variation in expansion coefficient with rare earth substitution is from $5.9 \times 10^{-6} /{ }^{\circ} \mathrm{C}$ to $7 \times 10^{-6} /{ }^{\circ} \mathrm{C}$ except for $\mathrm{Eu}$ which has a much higher $\alpha\left(8.31 \times 10^{-6} /{ }^{\circ} \mathrm{C}\right)$. The expansion coefficient value obtained for the $\mathrm{Y}-\mathrm{Si}$ $\mathrm{Al}-\mathrm{O}-\mathrm{N}$ glass $\left(6.3 \times 10^{-6} /{ }^{\circ} \mathrm{C}\right)$ is in good agreement with that of $\mathrm{Ho}-\mathrm{Si}-\mathrm{Al}-\mathrm{O}-\mathrm{N}$ glass $\left(6.4 \times 10^{-6} /{ }^{\circ} \mathrm{C}\right)$. $\mathrm{Y}$ and Ho have similar ionic radii $(0.89 \AA)$.

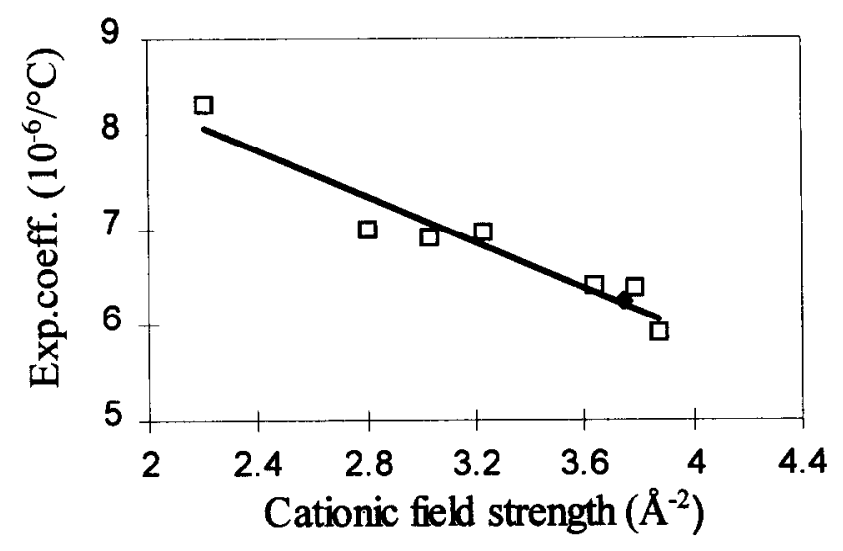

Fig. 6. The effect of $\mathrm{Ln}$ additives on the thermal expansion coefficient of standard cation compositions (data in increasing order of CFS correspond to $\mathrm{Eu}, \mathrm{Ce}, \mathrm{Nd}, \mathrm{Sm}, \mathrm{Dy}, \mathrm{Y}, \mathrm{Ho}$ and Er cations).

\subsection{Viscosity}

Figure 7 shows the variation of viscosity with temperature for the $\mathrm{Y}$ and various lanthanide glass compositions. From the figure, viscosity is seen to decrease in the order: $\mathrm{Er}>\mathrm{Ho} \geq \mathrm{Dy}>\mathrm{Y}>\mathrm{Sm}>$ $\mathrm{Ce}>\mathrm{Eu}$. The variation in viscosity observed between $\mathrm{Er}, \mathrm{Ho}$, Dy and $\mathrm{Y}-\mathrm{Si}-\mathrm{Al}-\mathrm{O}-\mathrm{N}$ glasses is rather small and this can be ascribed to similar ionic radii (Table 2) for the rare-earth cations. However, the oxides of Er, Ho and Dy may give liquids with similar characteristics to those formed when $\mathrm{Y}_{2} \mathrm{O}_{3}$ is used as a densifying additive with silicon nitride or sialons.

\subsection{Implications with respect to glass structure}

In oxynitride glass systems, it is well known that nitrogen substitution for oxygen results in significant increases in properties such as viscosity, glass transition temperature, hardness, etc. and this is larger than found by substituting cations at constant oxygen:nitrogen ratios. ${ }^{3,4,20}$ Both IR spectroscopy ${ }^{6}$ and Raman scattering ${ }^{21}$ investigations indicate that nitrogen is covalently bonded to silicon in the glass network leading to a more rigid cross-linked structure thus enlightening the role of nitrogen on glass property improvements.

The results of the present study show variations in properties with change of the rare-earth cation. Properties such as density, hardness, glass transition temperature and viscosities of the $\mathrm{Ln}-\mathrm{Si}-\mathrm{Al}-$ $\mathrm{O}-\mathrm{N}$ glasses increase with increasing cationic field strength (decreasing ionic radius). The molar volumes and thermal expansion coefficients of the $\mathrm{Ln}-\mathrm{Si}-\mathrm{Al}-\mathrm{O}-\mathrm{N}$ glasses decrease with increasing cationic field strength with the exception of the Eu glass. All these properties, in general, appear to vary linearly with ionic size of the rare-earth cation. Shelby and Kohli ${ }^{15}$ found similar linear trends between the ionic radius of the rare-earth cation and properties such as glass transition temperature and thermal expansion in rare-earth alumino-silicate glass systems. In addition, some indications of a linear trend were found by Ohashi et al. ${ }^{13}$ who attempted to correlate molar volume and glass transition temperature of a series of $\mathrm{Ln}$ $\mathrm{Si}-\mathrm{O}-\mathrm{N}$ glasses with rare-earth ionic field strength. In contrast, recent studies by Lemercier et al. ${ }^{22}$ on structure-property relationships in two series of oxynitride glasses in the $\mathrm{Y}-\mathrm{Si}-\mathrm{Al}-\mathrm{O}-\mathrm{N}$ system, with varying $\mathrm{Al} / \mathrm{Si}$ and $\mathrm{Al} / \mathrm{Y}$ ratios, showed nonlinear variation in properties and these have been attributed to the changes in the overall glass structure. Their Raman scattering studies showed that for a constant yttrium content, the increase of the $\mathrm{Al} / \mathrm{Si}$ ratio results in the replacement of $\mathrm{Si}-\mathrm{O}-\mathrm{Si}$ bridgings by $\mathrm{Al}-\mathrm{O}-\mathrm{Si}$ ones, while for constant silicon content compositions the increase of $\mathrm{Al} / \mathrm{Y}$ ratio 


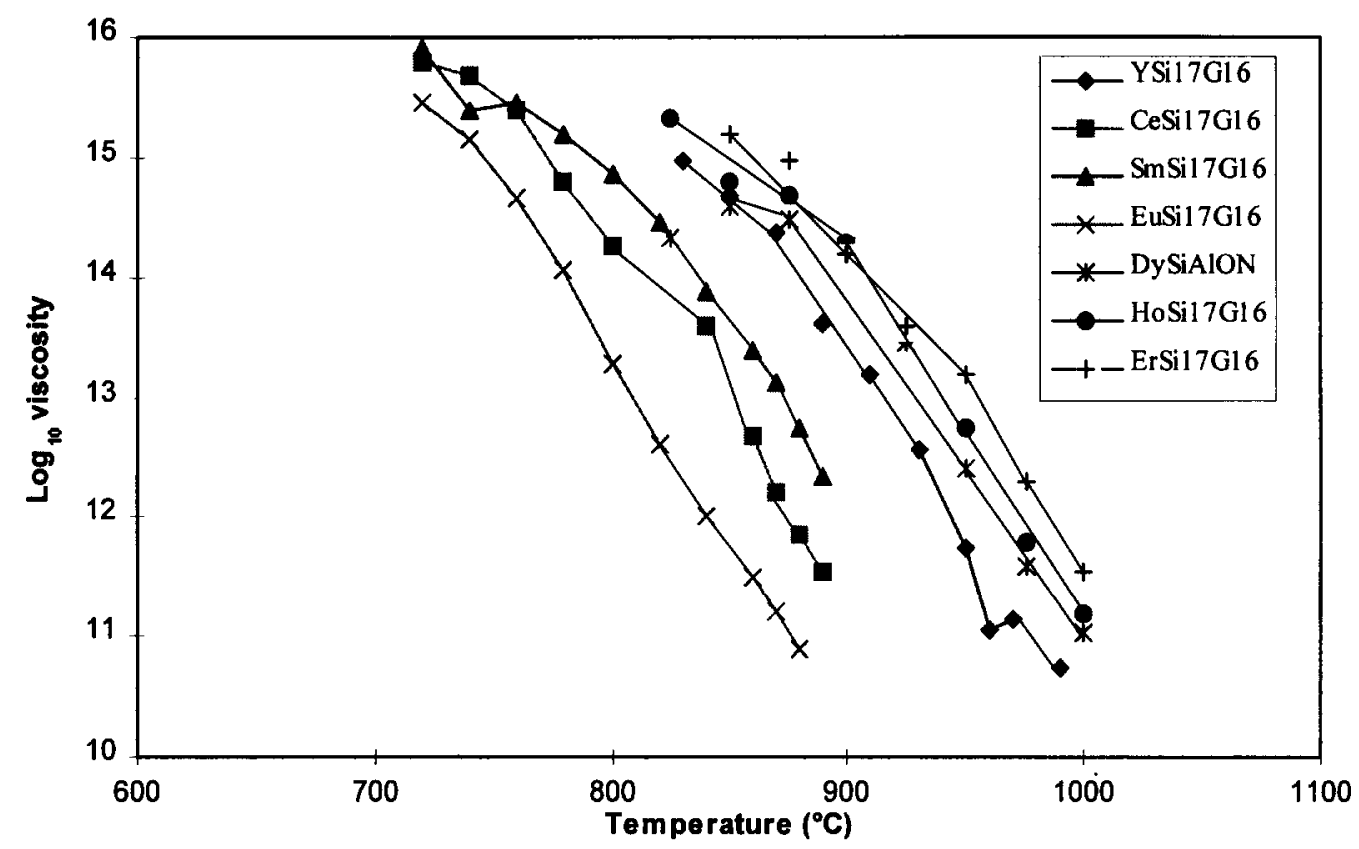

Fig. 7. Change in viscosity with temperature for $\mathrm{Y}$ and various $\mathrm{Ln}-\mathrm{Si}-\mathrm{Al}-\mathrm{O}-\mathrm{N}$ glass compositions.

results in the continuous replacement of two nonbridging oxygens by two Al-O-Si linkages. In a study of yttrium alumino-silicate glasses, typical co-ordination numbers for oxygen around $\mathrm{Al}$ are 4,5 and $6 .^{23}$ The relative number of differently co-ordinated species has been found to increase with $\mathrm{Al}: \mathrm{Si}$ ratios and decrease with $\mathrm{Al}: \mathrm{Y}$ ratios in $\mathrm{Y}-\mathrm{Si}-\mathrm{Al}-\mathrm{O}-\mathrm{N}$ glasses. ${ }^{22}$

It is known that in some complex oxides, trivalent rare-earth ions take a higher co-ordination state compared with other trivalent cations such as $\mathrm{Al}^{3+} .{ }^{24}$ This has been attributed to the strong ionicity of the $\mathrm{Ln}-\mathrm{O}$ bond and an ionic size large enough to accommodate co-ordination numbers (CNs) larger than or equal to 8 . The ionicity of the Ln-O bond changes little depending on the size or field strength of the rare-earth element. As a result, rare-earth cations can take different $\mathrm{CN}$ depending on their size. If this is true then one would not expect a linear variation in properties with either ionic size or field strength. The existence of such a linear trend in various properties, as seen from the present study, appears to suggest that the structures of these $\mathrm{Ln}-\mathrm{Si}-\mathrm{Al}-\mathrm{O}-\mathrm{N}$ glasses are not significantly changed by rare-earth substitution. In other words, the overall glass structure remains the same and the property changes appear to solely depend on the modifier cationic ficld strength. Further, cationic field strength controls the effective cage size of the $(\mathrm{Si}, \mathrm{Al})(\mathrm{O}, \mathrm{N})_{4}$ tetrahedral units. If substitution of rare-earth cation by another results in an increase of $\mathrm{CN}$ then the effective cage size would also be expected to increase, resulting in the expansion of the glass structure. The linearity observed with the property changes caused by the rare-earth substitution, in particular molar volume, indicates no such change in $\mathrm{CN}$.

Further, if it is assumed that the overall glass structure comprises $(\mathrm{Si}, \mathrm{Al})(\mathrm{O}, \mathrm{N})_{4}$ tetrahedra coupled together according to the ideas of Zachariasen, ${ }^{24}$ then the field strength of the modifying cation will directly control the level of modification of the glass structure. This being the case then $(\mathrm{Si}, \mathrm{Al})_{\mathrm{x}}(\mathrm{O}, \mathrm{N})_{\mathrm{y}}$ networks will be bridged by $\mathrm{Ln}$ cations. The smaller the cation and therefore, generally, the higher its field strength, the more closely the $(\mathrm{Si}, \mathrm{Al})_{\mathrm{x}}(\mathrm{O}, \mathrm{N})_{\mathrm{y}}$ units within the networks can approach each other. This will result in a decrease in molar volume with increasing cationic field strength which is indeed observed. As the field strength of the Ln cations increases, the attractive forces between $\mathrm{Ln}^{\mathrm{x}}+$ and surrounding structural units increase. If this is the case then properties such as microhardness and $\mathrm{Tg}$ should increase whilst CTE values should decrease. Again these effects can be observed as shown above.

On the basis of the above it can be argued that the overall arrangement of $(\mathrm{Si}, \mathrm{Al})_{\mathrm{x}}(\mathrm{O}, \mathrm{N})_{\mathrm{y}}$ networks remains similar for each of the $\mathbf{L n}-$ $\mathrm{Si}-\mathrm{Al}-\mathrm{O}-\mathrm{N}$ glasses and that $\mathrm{Ln}$ cation size and field strength control property changes. In summary, all these factors could mean that the cationic field strength of the rare-earth ion is responsible for the property changes observed. In addition, the size of the rare-earth cation is also of considerable importance for acquiring desirable properties. Since the field strength varies with the reciprocal of the ionic radius, the relative importance of the field strength and ionic size cannot, be separated. 


\section{Conclusions}

1. Homogeneous glasses containing 17 equivalent $\%$ nitrogen have been prepared in various $\mathrm{Ln}-\mathrm{Si}-\mathrm{Al}-\mathrm{O}-\mathrm{N}$ systems (where $\mathrm{Ln}=\mathrm{Y}, \mathrm{Ce}$, $\mathrm{Nd}, \mathrm{Sm}, \mathrm{Eu}, \mathrm{Dy}, \mathrm{Ho}$ and $\mathrm{Er}$ ). The colours of these glasses vary depending on the rare-earth cation used.

2. Density, hardness, glass transition temperature and viscosities of the $\mathrm{Ln}-\mathrm{Si}-\mathrm{Al}-\mathrm{O}-\mathrm{N}$ glasses increase with increasing cationic field strength (decreasing ionic radius). The molar volume and thermal expansion coefficient of the $\mathrm{Ln}-\mathrm{Si}-\mathrm{Al}-\mathrm{O}-\mathrm{N}$ glasses decrease with increasing cationic field strength with the exception of the Eu glass. All these properties, in general, appear to vary linearly with cationic field strength or ionic size of the rare-earth cation.

3. Substitution of one $\mathrm{Ln}$ cation by another appears to cause no change in the overall glass structure and the property changes observed are solely dependent either on the cationic field strength or ionic radius of the rare-earth cation.

\section{Acknowledgement}

The authors are grateful for financial support for this project under an entrustment contract from the Fine Ceramics Research Association, Japan.

\section{References}

1. Hampshire, S., Nitride ceramics. In Materials Science and Technology, Vol. 11, ed. W. Cahn, P. Haasen and E. J. Kramer, Weinheim, Germany, 1994, pp. 119-171.

2. Hampshire, S. and Jack, K. H., The kinetics of densification and phase transformation of Nitrogen ceramics. Proceedings of the British Ceramic Society, 1981, 31, 37-49.

3. Falk, L. K. L. and Dunlop, G. L., Crystallisation of the glassy phase in an $\mathrm{Si}_{3} \mathrm{~N}_{4}$ material by post sintering heat treatments. J. Mat. Sci., 1987, 22, 4369-4376.

4. Gazza, G. E., Effect of yttria additions on hot pressed $\mathrm{Si}_{3} \mathrm{~N}_{4}$. Ceramic Bulletin, 1975, 54, 779-781.

5. Shillito, K. R., Willis, R. R. and Bennet, R. B., Silicon metal oxynitride glasses. Journal of the American Ceramics Society, 1978, 61(11-12), 537.

6. Loehman, R. E., Preparation and properties of oxynitride glasses. J. Non. Cryst. Solids, 1983, 56, 123-134.
7. Hampshire, S., Drew, R. A. L. and Jack, K. H., Viscosities, glass transition temperatures and microhardness of $\mathrm{Y}-\mathrm{Si}-\mathrm{Al}-\mathrm{O}-\mathrm{N}$ glasses. Journal of the American Ceramic Society, 1984, 67, C46 47.

8. Hampshire, S., Drew, R. A. L. and Jack, K. H., Oxynitride Glasses. Phys. and Chem. of Glasses, 1985, 26(5), 182-186.

9. Makishima, A., Mitomo, A., Ii, N. and Tsutsumi, M., Microhardness and transparency of an $\mathrm{La}-\mathrm{Si}-\mathrm{O}-\mathrm{N}$ oxynitride glass. Journal of the American Ceramic Society, 1983, 66, C55-56.

10. Rocherulle, J., Verdier, P. and Laurent, Y., Preparation and properties of gadolinium oxide and oxynitride glasses. Mater. Sci. Eng., 1989, 82, 265-268.

11. Mandal, H., Thompson, D. P. and Ekström, T., Heat treatment of $\mathrm{Ln}-\mathrm{Si}-\mathrm{Al}-\mathrm{O}-\mathrm{N}$ glasses. Key Eng. Mater., 1992, 72-74, 187-204.

12. Murakami, Y. and Yamamoto, H., Properties of oxynitride glasses in the $\mathbf{L n}-\mathrm{Si}-\mathrm{Al}-\mathrm{O}-\mathrm{N}$ systems $(\mathrm{Ln}=\mathrm{Rare}$ earth). Journal of the Ceramic Society of Japan, 1994, 102(3), 231-236.

13. Ohashi, M., Nakamura, K., Hirao, K., Kanzaki, S. and Hampshire, S., Formation and properties of $\mathrm{Ln}-\mathrm{Si}-\mathrm{O}-\mathrm{N}$ glasses. Journal of the American Ceramic Society, 1995. 78(1), 71-76.

14. Trouton, F. T., Coefficient of viscous traction and its relation to that of viscosity. Proceedings of the Royal Society (London), 1905, 77, 425.

15. Shelby, J. E. and Kohli, J. T., Rare-earth aluminosilicate glasses. Journal of the American Ceramic Society, 1990, 73(1), 39-42.

16. Shannon, R. D. and Prewit, C. D., Effective ionic radii and systematic studies of interatomic distances in halides and chalcogenides. Acta Cryst., 1969, B25, 928.

17. Piriou, B., Ecole Centrale, Paris, personal communication, 1995.

18. Tanabe, S., Hirao, K. and Soga, N., Elastic properties and molar volumes of rare-earth aluminosilicate glasses. Journal of the American Ceramic Society, 1992, 75(3), 503-506.

19. Ishii, Y., Arai, K., Namikawa, H., Tanaka, M., Negishi, A. and Handa, T., Preparation of cerium activated silica glasses: phosphorus and aluminium codoping effects on absorption and fluorescence properties. Journal of the American Ceramic Society, 1987, 70(2), 72-77.

20. Hampshire, S., Oxynitride glasses and glass-ceramics. Proceedings of Materials Research Society Symposium Vol. 287, Materials Research Society, Pittsburgh, PA, 1993, pp. 93-104.

21. Rouxel, T., Besson, J. L., Rzepka, E. and Goursat, P., Raman spectra of YSiAION glasses and ceramics. J. Non. Cryst. Solids, 1990, 122, 298-304.

22. Lemercier, H., Rouxel, T., Fargeot, F., Besson, J. L. and Piriou, B., Yttrium oxynitride glasses: structure and mechanical properties-elasticity and viscosity. J. Non. Cryst. Solids (in press).

23. Kohli, J. T., Shelby, J. E. and Frye, J. S., A structural investigation of yttrium aluminosilicate glasses using ${ }^{29} \mathrm{Si}$ and ${ }^{27} \mathrm{Al}$ magic angle spinning nuclear magnetic resonance. Phys. Chem. Glasses, 1992, 33(3), 73-78.

24. Zachariasen, W. H., The atomic arrangement in glass. Journal of the American Ceramic Society, 1932, 54, 3841-3851. 